\title{
Silence and the politics of compassion. Commemorating slavery in the Netherlands
}

\begin{tabular}{|r|l|}
\hline Journal: & Social Anthropology/Anthropologie Sociale \\
\hline Manuscript ID & SAAS-15-019-OA.R1 \\
\hline Manuscript Type: & Original Article \\
\hline Keywords: & slavery, the Netherlands, memory, politics of compassion, race \\
\hline Abstract: & $\begin{array}{l}\text { The national slavery memorial in Amsterdam, unveiled in 2002, was meant } \\
\text { to 'break the silence' about slavery. However, the memorial did not } \\
\text { succeed in bringing about a definitive rupture because it became part of an } \\
\text { already existing discourse. To 'break' this silence has proven to be difficult } \\
\text { indeed, if not impossible, precisely because slavery was not 'absent' from } \\
\text { the historical record. Instead, slavery is part and parcel of the ways the } \\
\text { nation is embodied in a particular structure of feeling I call a politics of } \\
\text { compassion. }\end{array}$ \\
\hline
\end{tabular}

\section{SCHOLARONE $^{\text {m }}$}

Manuscripts 
On 3 April 2008, Rita Verdonk, a former politician of the liberal conservative party VVD, launched her political movement Trots op Nederland (Proud of the Netherlands) with an ode to a glorious past. 'Dutch culture', she claimed, had emerged through the struggle of 'our ancestors', giving birth to democratic values such as the freedom of speech and religious freedom. 'This culture, our traditions, our uniqueness (eigenheid), that's what we are proud of. That's the Netherlands!' But there is, she continued, an 'away-with-us movement' that is jeopardizing this culture. 'They even question the Saint Nicholas celebration. And they want to put up slavery memorials everywhere so as to paint us black.' This was nonsense, she continued, because 'Dutch people simply do not have it in them to discriminate! We have been a hospitable people for centuries.' But this hospitality must now cease, she concludes. 'Enough! There are limits. Because, people, if our Dutch culture disappears, so will our values and liberties.'

Verdonk's existential anxiety about Dutch culture and identity being subsumed in a multicultural 'drama' dovetails with postcolonial melancholia over past greatness lost (cf. Gilroy 2005). This articulation suggests that: (1) today's multiculturalism remains entangled with the colonial past, and (2) these are eminently emotional entanglements.

Verdonk and her movement have now disappeared, but for a brief period she embodied a sentiment that continues to dominate political and social life in the Netherlands today. This is the desire for community, in which an organic body of 'the people' is pit against both racialized allochtones (a term used in the Netherlands to refer to Dutch citizens with a migrant background, cf. Geschiere 2009) and the elites who threaten 'Dutch culture'. Observers of this shift towards parochialism have time and again expressed their surprise: how could a country that considers itself and is known internationally to be tolerant, open, and progressive embrace, all of a sudden, such a xenophobic and isolationist stance (Geschiere 2009)? This seeming tension between cosmopolitan ambition and parochial practice has been the subject of much recent research on sexual politics (Mepschen, Duyvendak, and Tonkens 2010; Midden 2014; Mepschen, Duyvendak, and Uitermark 2013; Uitermark, Mepschen, and Duyvendak 2013; Verkaaik and Spronk 2011) and the rise of right wing populism (Oudenampsen 2013; Prins 2002). Clearly, parochialism and cosmopolitanism can co-exist (cf. Meyer and Geschiere 1999; Comaroff and Comaroff 2009). But how is it possible to claim, as Verdonk does, to be cosmopolitan and at the same time advocate cultural closure? How can one make sense of the paradoxical claim that the assault on the 'Dutch culture' of openness and benevolence necessitates building a cultural fortress?

I think the answer lies in Verdonk's affective logic which implies a shift in how states understand citizens, from 'rational, individual and calculative subjects ... [to] affective subjects in search of attachments to something in common' (De Wilde 2015, 22; Balkenhol 2015; Mepschen 2016; Muehlebach and Shoshan 2012). In Verdonk's narrative, the nation appears as a sensitive being whose empathy towards others is its distinguishing characteristic, indeed its pride. But it is precisely this sensitivity that makes the nation vulnerable. In Sara Ahmed's words, this is a cultural politics of emotion in which "soft touch" becomes a national character' (Ahmed 2004, 2): 'the metaphor of "soft touch" suggests that the nation's borders and defences are like skin; they are soft, weak, porous and easily shaped or even bruised by the proximity of others. It suggests that the nation is made vulnerable to abuse by its very openness to others' (Ahmed 2004, 2, emphasis MB). The Dutch nation, personified, becomes both the object and the subject of compassion: the object of compassion because it is portrayed as suffering and in need of help, the subject of compassion because the Dutch nation, identity, and people are themselves presented as compassionate. Verdonk 
engages here in what I call a politics of compassion: the political mobilization of a particular emotion in negotiations over the nation, citizenship, and belonging.

Whereas Verdonk mobilizes compassion for a parochialist project of cultural closure, the politics of compassion in the Netherlands informs a wider political field in which the meaning and practice of compassion are highly contested. In this field, compassion can be mobilized by reactionary forces aiming for cultural closure, but also offers an idiom in which these forces can be challenged. By mapping these dynamics, I offer a more complex understanding of the postcolonial present in the Netherlands that goes beyond simple oppositions of 'white' and 'black', 'silence' and 'voice', 'denial' and 'recognition'.

\section{Slavery and compassion}

Verdonk locates the essence of Dutch culture in a glorious past: in Dutch traditions, in the struggle of 'our' ancestors against oppression, and in the long history of hospitality that distinguish the Dutch as a people. But while Verdonk and the new nationalists may have been the loudest exponents of reinstating 'Dutch identity', they were anything but lone voices. Beginning in the 1980s and 1990s, politicians across the board had begun pressuring minorities to 'integrate' into 'Dutch culture'. However, this led to searching questions about who must integrate, what they should integrate into, and what integration is in the first place (Schinkel 2007, 20): 'If the allochtoon had to integrate, an obvious question was how to define into what she or he had to integrate. However, defining this turned out to be not an easy job' (Geschiere 2009, 133). In this search for Dutch identity and culture, the past seemed to hold the answers. Cultural heritage, history, and tradition became the new buzzwords, uniting politicians, intellectuals, the cultural sector and civil institutions. In May 2006, Jan Marijnissen of the Socialist Party and Maxime Verhagen of the Christian Democratic Appeal pleaded in an op-ed to 'save our historical consciousness' and proposed a National Historical Museum modelled on the German Haus der Geschichte because, they argued, 'it seems as though we no longer have a shared identity'. 'Also in 2006, the Van Oostrom Commission, named after its chairman historian Frits van Oostrom, unveiled the first national historical canon (De canon van Nederland): 'what everybody in any case ought to know about the history and culture of the Netherlands'. In 2012 the Dutch government ratified the UNESCO Convention for the Safeguarding of Intangible Cultural Heritage.

The proponents of these projects hoped that education about the past would foster historical awareness, which in turn would lead to mutual understanding between 'cultures' and thus more social cohesion. But what these initiatives failed to recognize was that emotionally charged concepts like 'nation', 'people', 'tradition', and 'history' are not simply about factual knowledge (a kind of Habermasian notion of rational argumentation). Historical knowledge, precisely because it is so entangled with questions of identity, is always also 'known' emotionally.

This entanglement of knowledge and emotions also riddled the commemoration of slavery in the Netherlands from its very inception. While the idea that knowledge about the past would lead to understanding, recognition, and ultimately redress was at the heart of the initiative for a national slavery memorial, those involved also appealed to emotions from the outset. Foreshadowing the ensuing debates over history and cultural heritage, black grassroots organizations had recognized the growing investment in the past and national culture already in the early 1990s. In 1993 the Committee 30 June/1 July organized contemplative gatherings on Suriname Square in Amsterdam to commemorate the shared history of the Netherlands and its Caribbean colonies, including transAtlantic slavery (Balkenhol 2014). Slavery emerged as a national issue in 1998 when the AfroEuropean women's organization Sophiedela, chaired by the Afro-Surinamese politician Barryl 
Biekman, petitioned for a memorial to commemorate the victims of the Dutch slave trade and slavery.

In their 1998 petition to the Dutch parliament, Sophiedela demanded that slavery be recognized as part of Dutch history. The petition was a 'call for recognition, attention, and the recording of [the African Surinamese] history', by which the petitioners meant education that recognizes the 'damaging side of slavery'. The petitioners, however, wanted to raise awareness not simply by revealing the 'facts'; they presented these 'facts' in a way that was certain to evoke emotional response. The petition showcased a long list of atrocities, including for instance a form of punishment in which 'a hook was driven through the skin or under the ribs of the slaves and as if this terrible pain was not enough red hot tongs were wedged in the slaves' flesh'. With these graphic images, the petitioners not only wanted to unmask the truth about slavery; showcasing this kind of violence was necessary to appeal to the nation's compassion:

We are aware, chairman, that the Netherlands feel strongly about freedom and tolerance. ... Much has been sacrificed for the preservation of this freedom. We Surinamese, too, participate fully and with a deep sense of respect and compassion in the Dodenherdenking (Commemoration Day) on 4 May and the celebration of freedom on 5 May. Moreover, the policy of the Dutch government has always seen fit to support the victims of war in one way or another. ... This good work is not only known to African Surinamese, but also internationally. ... [l]t is therefore obvious that they will appeal for support where they know attention has traditionally been paid to such issues: the representational organ of the Dutch people.

One might expect a nation looking for positive identification to collectively reject such demands to own up to its violent past. Surprisingly, the confrontational strategy initially paid dividends: the Dutch parliament quickly accepted the proposal for a monument to slavery. Many people shared Biekman's relief that 'finally the moment has arrived when the Dutch government and the Dutch parliament officially recognize the Dutch slavery past as a historical fact' (Biekman 2002, 9). From cultural institutions to politicians, many agreed that slavery had been silenced, and that it was high time this silence was broken. During the high-profile bezinningsbijeenkomst (contemplative gathering) at Laurens Church in Rotterdam in 2001, André Kramp, international coordinator of the UNESCO Slave Route Project in Paris," delivered a speech in which he argued that the 'conspiracy of silence' around the mass deportations of Africans to the Americas needed to be broken (De Volkskrant, 2 July 2001). The Dutch Minister of Urban and Integration Policy (grotesteden- en integratiebeleid), Roger van Boxtel of the liberal conservative party D66, agreed: 'It is so important that our Dutch slavery past is stripped of the aura of secrecy and concealment. ${ }^{\text {.iii }}$

On 1 July 2000, State Secretary of Education, Culture and Science Rick van der Ploeg of the Labour Party had stated: 'Up until this day, the invisibility of slavery to a certain extent continues. Because the history of slavery does not fit into the often-praised self-image of the Netherlands as the tolerant and progressive nation of old. ${ }^{\text {iv }}$ Like van der Ploeg, literary scholar Joke Kardux argued that slavery had been 'erased from public consciousness' because 'the Netherlands' role in slaveholding and slave trading was so irreconcilable with [the Dutch] sense of national identity' (Horton and Kardux 2004, 51). Several other historians critically engaged with the 'deafening silence' that, they argued, characterised the Dutch attitude towards slavery in the nineteenth and twentieth centuries (Stipriaan 2005, 46) and that, according to them, endures monolithically and largely unchanged up until this very day: '[...] as a consequence of the long silence in the nineteenth and twentieth centuries, there are many who are perhaps only now beginning to leave slavery behind' (Stipriaan 2005, 57, translation MB; cf. Oostindie 2001). 
This initial success ironically became the memorial's greatest obstacle. Everyone who mattered seemed to agree. The memorial had promised to break the historical silence about slavery by 'unmasking' the truth. But as Paul Bijl observed, 'perhaps surprisingly, it is mostly [white, MB] Dutch people themselves who utter this lament [about forgetfulness]... Speakers, moreover, not only charge the other Dutch with amnesia, but also emphatically include themselves. "We have forgotten about our colonial past"' (Bijl 2012, 441). In other words, the simplistic notion of silence as erasure voiced by some critics of colonialism underestimated 'both the complexity and persistence of what they see as Dutch colonial forgetting' (Bijl 2012, 443). Having focused on 'unmasking' a repressed historical truth and the supposedly intentional actions of groups such as historians, the media, and the government, the wind was taken out of their sails by a compassionate stance that seemed to say: 'Yes! We are guilty.'

Paul Bijl examines how the structure of collective memory in the Netherlands excludes colonial memories by displacing them: 'the victims of colonialism are not memorable within a national context and there is no language available to discuss them as part of Dutch history' (Bijl 2012, 458). I focus on a complementary structure of feeling in which traces of colonialism do not lie 'outside national history' (Bijl 2012, 458) but are silenced through assimilation.

Both of these forms of memory - displacement and assimilation - surfaced when the slavery memorial was unveiled on 1 July 2002. The moment of the unveiling had been highly anticipated; Dutch people of African descent had travelled to the unveiling ceremony from all over the country. Who could fathom their disappointment when they learned that they could not attend the ceremony? Ten months after $9 / 11$ and less than two months following the assassination of politician Pim Fortuyn, and with high-ranking guests including the Queen and the Prime Minister in attendance, security for the ceremony was tight. Only invited guests, among them many representatives of black elites, were allowed near the monument, thus excluding a large number of 'ordinary' people. The image of people rattling the fences, excluded from the ceremony, merged with an iconography of black suffering that had already been well-established. Black people once more became the object of pity.

In the article 'Slavery monument evokes no emotions among whites', published in the daily broadsheet De Volkskrant of 1 July 2002, historian and journalist Sander van Walsum argued that the lack of interest on the part of 'white Dutch' jeopardizes the usefulness of the entire memorial project. While Van Walsum did not explain precisely how and why 'white Dutch' lacked interest in the project, he noted that this indifference was already apparent in 1963 , on the $100^{\text {th }}$ anniversary of abolition. Historian Gert Oostindie, who had himself been active in the memorial project, supports this view, contrasting the perspectives of 'simply indifferent' whites and emotionally involved (betrokken) blacks. Even Barryl Biekman, chair of Sophiedela and the national platform on slavery LPS, admitted that 'not all have the same sentiments' about slavery, implying that white people are emotionally detached from the subject.

Indifference, however, is neither the only nor the leading emotion when it comes to remembering slavery. For example, the conservative historian Piet Emmer once angrily remarked that people might 'have a go at [the monument] with a hammer', suggesting that there are many other emotions involved. At least for a moment, indifference turned into effervescence around 1 July 2002 as comments, opinions, vox pops, and background articles filled the front pages of the newspapers. Within the swirling attention for slavery and the memorial project, few were indifferent or dispassionate. 
Significantly, resentment towards commemorating slavery was time and again expressed through references to compassion. Some argued that compassion should be expressed towards all victims of slavery, not only select groups. Ironically, this included the white Dutch (who had fallen victim to 'Arab' slavery in the Mediterranean). In these dismissive statements, the Dutch nation was portrayed as compassionate. Syp Wynia, editor of the conservative weekly Elsevier, argued:

At the end of the twentieth century Surinamese immigrants discovered that if you want to achieve something in the Netherlands, morality is an effective strategy. They noted that the Dutch were receptive towards claims of moral inferiority. And that, vice versa, recognized victimhood leads to the granting of moral superiority to the victim. In this sense coping with the slavery past displays a typically Dutch character (Elsevier, 21 November 2015).

Silencing, in other words, here takes place by stylizing the Dutch nation as the victim of its own compassion. In these reactionary accounts, it is the supposed openness of the Dutch character that makes it vulnerable to moral blackmail.

These were influential voices, but compassion was also mobilized in affirmative ways. Especially after the monument's unveiling, many commentators also expressed sincere compassion with the black crowd who had been wronged once again. The daily newspaper Trouw published the following comment from a 'white' participant at the event:

I was at the unveiling of the National Slavery Monument, I am white and I was ashamed. Around me countless black fellow citizens, often in gorgeous traditional attire, by the video screen gliding in the mud of the rain-soaked park, kept at a distance by fences that were screened off with black plastic, patiently waiting for the formal guests to leave the area, before they could approach the monument themselves. How is it possible that those responsible for organizing this historic event could have made such a mistake? [Minister] Van Boxtel, you have hereby proven not to have understood much. The monument is the symbol of 1 July and the sons and daughters of slavery should have been in the first row (Trouw, 5 July 2002).

Other commentators also expressed compassion. Frenk der Nederlanden, a well-known columnist, described his experience on the front page of Het Parool:

An officer pushes a 14 year old Surinamese girl away and shouts: 'Distance!' An older black woman in colourful clothes is smashing her umbrella on the fences that keep her from laying a little flower by the slavery monument further on in the park. Mounted police try with all their might to prevent the angry crowd from pulling down the plastic-covered fences (Het Parool, 2 July 2002).

Similarly, Willem Breedveld, a long-time columnist and journalist at Trouw, wrote:

Imagine you are in a euphoric mood about finally being freed, only to find crush barriers in your way, forcing you to powerlessly watch others appropriate the ultimate place for this freedom. It can drive you mad. This is why I understand the anger that possessed the descendants of slaves [...] (Trouw, 2 July 2002).

In the aftermath of the unveiling ceremony, the dominant image was that of 'white' indifference or anger and 'black' disappointment and emotional pain. But as I have tried to show, the language of emotions was much more complex than this simple binary suggests. 
Emotional engagement with the memorial commemorating slavery nonetheless, and in different ways, related to a common theme: that of compassion. Whether mobilized politically to address the state (by grassroots organisations), dismissed as the perversion of a 'Dutch' sense of compassion (out of resentment), or embraced as an obligation for 'whites', slavery was understood as a moral issue that needed to be discussed in terms of compassion.

Whether critical or affirmative, compassion appears as a normative moral stance both deeply problematic and potentially transformative (cf. Spelman 1998). On the one hand, compassion signals a power relation that is implied in the distance it creates between a suffering and passive other and a compassionate and active self (Berlant 2004). On the other hand, compassion (unlike pity) can motivate political action and solidarity with the goal of changing this very hierarchy.

In short, the unveiling of the slavery memorial was not the sudden revelation of a well-kept secret, but an event marked by continuity rather than change. I therefore take 'silence' not as the absence of speech, but as a particular way of speaking - a language of emotions that, I will show, mobilizes compassion in particular. 'Language' here is understood as embodied and performative, as appealing to the emotions. The display of violence is essential in this emotional register, as it is necessary to bring into relief the magnitude of compassion. Silence, then, is better understood as a particular mode of remembering (cf. Bijl 2012, 444; Passerini 2003).

\section{Silence, colonialism, nation}

In History of Sexuality, Michel Foucault argued that Victorianism led not to the silencing of sexuality, but to 'a veritable discursive explosion' (Foucault 1978, 17). Precisely the effort to restrict sexuality in all spheres of people's lives made it necessary to manage it down to the minutest detail. Implementing the prohibition to talk about sex in secondary schools, for instance, meant that the entire institution was geared to the management of children's sexuality.

Paradoxically, this means that much discursive work must go into 'silencing': in order to silence slavery, one needs to talk about it. A similar point has been argued by Michel-Rolph Trouillot in his now classic Silencing the Past. Like Foucault, Trouillot understands 'silence' as discursive silence and not the absence of speech. The Haitian revolution, for example, was hotly debated in the French colonial metropole. What mattered was not the absence of speech about this event, but the failure of colonial politicians to conceive of the evidence of a mass movement of highly trained, motivated, and organized black Haitians as a revolution. Trouillot argues that eighteenth-century men and women saw the Haitian revolution as a 'historical impossibility' because the 'events that shook up Saint-Domingue from 1791 to 1804 constituted a sequence for which not even the extreme political left in France or in England had a conceptual frame of reference' (Trouillot 1995, 82). In other words, silencing the Haitian revolution was not achieved through a simple absence of speech, but through the use of certain registers of speech that were unfit to grasp the black Haitian as a historical subject. ${ }^{\vee}$ The discursive non-presence of slavery, then, can be framed as a kind of 'colonial aphasia' or an 'occlusion of knowledge' that is 'a dismembering, a difficulty speaking, a difficulty generating a vocabulary that associates appropriate words and concepts with appropriate things' (Stoler 2011, 125). This implies that a revelatory moment in which the 'truth' about slavery would be revealed and lead to a national act of self-discovery (Bijl 2012) was doomed to fail from the start. Indeed, the claim that such a moment is possible would reduce slavery to a mere 'event' that can be isolated historically and forgotten.

Following these understandings of silence as a specific form of discursive speech, my notion of the politics of compassion as a contested political field is a way to foreground the complexities of 
colonial memory and national self-image in the Netherlands. While there may be cases of deliberate erasure, exclusion, and repression, the evidence I have presented thus far suggests that there are other modes of colonial memory where slavery was not erased, but was assimilated into - and even became a constitutive element within - projects of nation-building. In this mode of colonial memory, it was even necessary to expose the violence of slavery.

\section{Presences}

The commemoration of slavery in the Netherlands began long before 2002. On 1 July 1962, a commemoration attracted some 1000 visitors from across the country (Bosma 2009, 88). The $100^{\text {th }}$ anniversary of abolition the following year drew larger numbers. A demonstration was organized by the Surinamese foundation Wi Eegie Sanie (Our Own Thing) in Amsterdam (Bosma 2009, 89), with 500 Surinamese-Dutch marching through the city carrying banners stating Fri moe de (Freedom must come) (Oostindie 2010, 165). Unlike today, these commemorations were focused less on black citizenship and Dutch racism (Essed and Hoving 2014) and more tied to anticolonial struggle (Bosma 2009; Oostindie 2010).

These commemorations attracted media and political attention. On 2 July 1963, commemorations in Amsterdam, The Hague, Zeist, Paramaribo, and Willemstad were front page news in the Nieuwe Rotterdamse Courant, including a sizeable photograph of the demonstration in Amsterdam. The chairmen of the upper and the lower houses of parliament conveyed their congratulations in telegraphs to the Antilles and Suriname. In Zeist, even the mayor attended the ceremony (NRC, 2 July 1963).

Three days earlier, the same newspaper had already published a full-page cultural supplement dedicated to slavery and abolition, covering white supremacy and racism, the slow and unenthusiastic process of abolition in the Dutch colonies, and the neglect of the welfare of the freed people. The supplement also included an image of the auction block from Benoit's Voyage à Surinam (1839) and a historical advertisement announcing the sale of a woman and her children (1832) - the same images that had played a crucial role in the creation of the national slavery memorial.

The Nieuwsblad van het Noorden was even more explicit in its full-page coverage of abolition. The article 1863: Wet afschaffing slavernij (1863: Law abolishing slavery) had as its subtitle: 'but for the negro slaves in the West, bondage remained a torturing reality for ten more years'. It begins:

One hundred years ago [...] slavery was abolished by law in the Dutch West Indian colonies. Finally. Because already 30 years earlier the slaves in the English colonies had been freed. 15 years later, the French colonies followed suit. Only the Netherlands was not in a hurry. It is embarrassing that in all seriousness, initial opinion was that the slaves should pay for their own freedom; it is also embarrassing that, once the slaves were freed, they were obliged to work on the plantations of their former masters for ten more years, under conditions that were all but the same as they had been before emancipation (Nieuwsblad van het Noorden, 29 June 1963).

But even before these events, slavery and the violence of slavery had been present in the public sphere. The historian C.K. Kesler, for example, published widely both in professional and popular media in the 1920s and 1930s. His 1929 article in the widely read leftist weekly De Groene Amsterdammer, 'Feest in Suriname', described the celebration of Keti Koti $i^{\mathrm{vi}}$ two months earlier. Much can be said about this article, but not that it erases violence: $:^{\text {vi }}$ 
[John Gabriel Stedman] tells of the Spanish rack, a form of punishment in which the victim, wedged into a triangular contraption of rods with their neck, arms, and knees, is beaten on their bare back with tough tamarind branches on street corners; of a rebellious slave, who, with his hands and feet bound, was hung from the gallows on a hook that had been driven under his ribs, and who was left there for a few days in his misery, until a compassionate soldier crushed the man's skull with the butt of his rifle, and many even more terrible stories. Those who read this book and other writings from this time will become convinced that during slavery, Suriname was a living hell for the negroes. As late as 26 January 1833, the arsonist Codjo was burned alive in public with two of his accomplices, just like it was done in the Middle Ages (De Groene Amsterdammer, 31 August 1929).

Note that the soldier 'crushed the man's skull' as an act of compassion. In his numerous publications in the West Indian Guide, Kesler frequently included highly graphic descriptions of the most unspeakable atrocities. In 1932, for example, he published an article on the two famous fires that destroyed much of Suriname's capital, Paramaribo, in 1821 and 1832. Although the article makes a technical argument about economic development and fire safety, Kesler turns to moral issues.

The 1832 fire was deliberately set by Kodjo, Mentor, and Present, three black men who aimed to spark a revolution by setting fire to the city. Unable to grasp the significance of the event as an act of anti-colonial resistance, Kesler qualifies this action as 'fantastic' and absurd. Nonetheless, he seems to care for the men, describing the details of their punishment at length: burning at the stake, beheading, and the public display of their severed heads.

Nor did Dutch literature and intellectual thought avoid the subject of slavery. Alison Blakely found that 'The most common theme in Dutch literature on blacks is the Dutch experience with African slavery' (Blakely 1993). G.A. Bredero, for example, condemned slavery as early as 1617 in his play Moortje:

Inhumane practice! Godless Knavery! / That men sell men into chattel slavery! / There are some in this city who ply such trade. / In Fornabock, but it will not escape God's gaze.

But Bredero's stance is 'ambivalent', both opposing and condoning slavery:

This [indictment of slavery] did not, however, prevent Bredero from presenting his lover a black girl as a gift. Bredero is thus an early example of the ambivalence which would continue in Dutch society concerning ethical principles and practices related to slavery. This would be apparent both in the lives of various thinkers and in their works (Blakely 1993, 172).

There were even some early abolitionist novels in the Netherlands. An English novel, (Orinooko) The History of the Royal Slave by Aphra Behn (1688), was about an African lured into slavery who killed his wife so that she could avoid enslavement, and who was then cruelly mutilated before he could commit suicide (Blakely 1993, 172).

Two others, Reinhart by Elisabeth Maria Post (1791-92) (Paasman 1984) and De Middelburgsche Avonturier published anonymously in 1760, depicted 'good' slave owners. Other works defended slavery as a necessary evil; yet others romanticized the lives of planters. 'These contrasting outlooks concerning slavery suggest the complexity of this issue for those who gave it serious thought' (Blakely 1993, 176).

In 1780, a novel appeared in Batavia, the capital city of the Netherlands East Indies, describing the murder of an unusually cruel mistress by a wronged slave. While the play based on this event was staged in The Hague in 1801, the East Indies gentry succeeded in having it banned from the stage. 
According to a witness, this led to a proliferation of interest in slavery rather than its 'erasure': 'the bookseller (as he told me himself) sold infinitely more copies of the play that day than what he had sold in the whole preceding six months' (Blakely 1993, 176-77).

All this suggests that 'erasure' was at best one of many strategies to manage the memory of slavery. At least in some cases, slavery was present in very explicit ways, both in historical scholarship as well as in the general public sphere. I therefore agree with Gert Oostindie who has argued that '[i]n Dutch historiography, there has long been an interest in slavery. There is thus no active repression, but neither is there a broad awareness' (Oostindie 2010, 163). This latter statement, however, invites critical examination of what constitutes awareness. The fact that Kesler's and other historical descriptions of violence often resemble those on display in commemorations of slavery today should make us pause. What kind of awareness does the display of violence foster?

Judging by their insistence on the violence and injustice of slavery, the historical sources quoted above seem to be aware. Not only do they seem aware of the violence and injustice, they also take the only possible humanist position by condemning slavery. While it seems difficult to fault such a position for ignoring, neglecting, or even erasing the violence of slavery, the double bind remains: taking the position of compassion always also implies hierarchy (Berlant 2004; Sontag 2004). The showcasing of violence and injustice becomes constitutional for a humanist subject that both distances herself from injustice and violence and at the same time dissociates herself from taking responsibility for her own history.

\section{The politics of compassion}

Kesler expresses his moral outrage over the violence committed against the enslaved - the inhumanity of being burned at the stake or beheaded - especially as these sentences were also passed down on a woman. Exasperated, he laments that nobody showed 'compassion' (medelijden) for the victims: 'Apparently, in general it was believed, from high to low, that the punishment was a justified retaliation for the crimes committed' (Kesler 1932, 172).

For Kesler, the three black men who set fire to Paramaribo were no resistance heroes. He saw them as criminals, but also as victims that deserved compassion. His concern with the extreme and unjust violence they suffered, however, not only draws attention to the fate of the enslaved, but also to compassionate Kesler himself.

Showcasing images of violence, I argue, functions to establish a compassionate subject and a suffering object. The graphic descriptions of violence enable rather than contradict the idea of a caring subject. One can even 'crush a man's skull' in the name of compassion! Indeed, the more intense the violence, the more significant its compassionate condemnation, both for individuals such as Kesler and for collective subjects such as the nation.

As I discussed above, Kesler in De Groene Amsterdammer dwelled at length on the most repelling images of slavery. Detailed descriptions of torture and suffering served a specific role in his narrative - to build up to the concluding statement: 'No wonder that ... the governor, who conveyed the message of freedom, was venerated as "Father" Van Landsberge for a long time. No wonder, also, that an even greater veneration emerged for the mighty King [...].'

The images of cruelty are necessary to make the veneration of the King logically acceptable. Slavery, and the iconic images of violence associated with it, are instrumentalised in what Susan Buck-Morss has called a 'root metaphor' connoting everything that is evil about power relations, but in turn portraying European nations - who had themselves instituted these very power relations - as 
enlightened beacons of liberty (Buck-Morss 2009). Kesler's way of framing slavery suggests that he not so much 'erased' slavery but embraced it. Here, images of violence are not excluded and suppressed, but assimilated in a process of nationalist meaning-making. Kesler imagines the Netherlands as a compassionate nation, which suggests that, at least in Kesler's narrative, the national self-image of tolerance and compassion did not emerge despite slavery, but through it.

In 1956, historian C.C. Goslinga portrayed slavery itself as a trajectory of emancipation, set in motion by the compassion of the slaving nation and the Protestant Church: 'The only important fact that transcends the limited sphere of colonial events from the French Time until the First World War, is, as far as the West is concerned, the Emancipation of the slaves, which was announced on July 1 , 1863.' This 'only important fact', according to Goslinga, was not the outcome of the struggle of the enslaved, but the 'deed of Thorbecke's second ministry during King Willem III's administration', a King who 'even received the nickname "The Good" from the Creoles' and was venerated by former slaves for his act of compassion. Not only the signing of the Emancipation law, but slavery itself becomes a compassionate act:

[A]s contradictory as that may sound, emancipation already begins with slavery itself. After all, emancipation is not merely one deed, it is also a process, and every measure, regulation, decision, or bill of which the slave is subject or object, constitutes a link that eventually brings us to the end of a chain of three centuries of intervention and care for the unpaid work force and to this memorable July 1, 1863, when Mgr. Kistemaker, then Apostolic Vicar and Bishop of Curaçao and Subordinates, celebrated the release with a solemn Mass in the presence of Governor Crol and other authorities (Goslinga 1956, 9, emphasis MB).

Kesler, Goslinga and many others do not deny the reality of slavery and its inherent violence. In order to understand how it has been possible to silence while speaking, we need to look at the specific rhetorical strategies through which slavery was present in Dutch discourse. At least in the sources I discuss here, slavery was not so much excluded from discourse as semantically overdetermined in the service of nationalist and religious aims. Slavery became an 'easy metaphor' (Buck-Morss 2009) in which the Dutch nation and the Christian faith appear as institutions excelling in the care of others.

Even when slavery was displaced, the nation could be imagined as compassionate. Hence the stunning popularity of Harriet Beecher Stowe's Uncle Tom's Cabin, translated into Dutch in 1853 and reprinted 120 times since. Uncle Tom's Cabin not only displaced slavery as something that happened elsewhere (Bijl 2012); it also allowed imagining the Dutch nation as compassionate to the suffering of others.

Compassion here emerges as an ambiguous emotion indeed. As Lilie Chouliaraki has argued,

Whereas [the] moral emphasis on pity has enabled, partially but significantly, the alleviation of suffering among large populations in modern times, it has simultaneously established a dominant discourse about public action that relies heavily on the visuality of suffering and on its emotional language of emergency (Calhoun 2010). It is this reliance that, in Arendt's famous critique, displaces politics into the 'social question' - it displaces the long-term concern with establishing structures of justice with the urgent concern for doing something for those who suffer (Chouliaraki 2012, 79).

I share Hannah Arendt's concern, but also understand the politics of compassion as a political field in which, as Paul Gilroy has argued, there is 'potential for political action and pedagogy' (Gilroy 2009, 46). I agree with Gilroy that compassion cannot be rejected simply 'because campus anti-humanism doesn't approve of the dubious aesthetic and moral registers in which an un-exotic otherness was 
initially made intelligible' (Gilroy 2009). The point is not to reject and condemn appeals to compassion as sentimentality or hypocrisy, but to recognize that compassion remains a problematic paradigm within which appeals to political action continue to be made. By employing the term 'politics of compassion', my aim is not to dismiss humanitarianism, but to point out that in the case of the commemoration of slavery, compassion and nationalism are two sides of the same coin.

\section{Conclusion}

How can one claim to be cosmopolitan while making parochialism one's political practice? In an attempt to answer this question, I have advanced two related arguments, one about colonial memory, the other about multiculturalism. First, I argued for a complex understanding of colonial memory that goes beyond dichotomies of 'black' and 'white', 'truth' and 'silence', and 'remembering' and 'forgetting'. The historical evidence I discussed underscores that historical 'silence' is a complex, even contradictory phenomenon that in some cases even showcases violence and injustice. Historians, journalists, and playwrights have often emphasized the suffering of the enslaved to appeal to humanist sensibilities. But this emphasis on suffering is eclipsed when - in both populist and mainstream rhetoric - the focus shifts from suffering to compassion. In such narratives, colonial violence is necessary to imagine the Netherlands as a compassionate nation. I have called this the politics of compassion, the politics of a particular emotion that silences the fact that it was Dutch slave traders and owners who inflicted the suffering.

Second, I have argued that debates over national identity and multiculturalism, in which the nation and its citizens are increasingly framed in affective terms, also function according to this politics of compassion. While the way in which emotions such as compassion are now being implemented in neoliberal models of governance may be new, the language of emotions in which this is situated historically has roots in colonial modes of identification and othering.

Finally, in light of the politics of historical redress that I have discussed, the politics of compassion has significant implications for how a postcolonial future can be refashioned, to use David Scott's (1999) term. The idea of a definitive break, in which the past can finally be left behind, will have to be abandoned. Instead, we need to understand the complex structures in which the colonial past informs the multicultural present, including particular structures of feeling. As I have shown, these structures of feeling are not in and of themselves impediments to alternative postcolonial futures. While the politics of emotions discussed in this article have interfered with initiatives for colonial redress, emotions have also provided a means for articulating them in the first place. These are the dynamics of colonial memory and the postcolonial present. They cannot be addressed in a rationalist framework based on knowledge and facts. Instead, we need to understand how exactly knowledge is entangled in structures of feeling. 
References

Ahmed, Sara. 2004. The Cultural Politics of Emotion. New York: Routledge.

Balkenhol, Markus. 2014. "Tracing Slavery. An Ethnography of Diaspora, Affect, and Cultural Heritage in Amsterdam." PhD Dissertation, Amsterdam: Vrije Universiteit Amsterdam.

- - . 2015. "Zwarte Piet, Racisme, Emoties." Waardenwerk 62: 36-46.

Berlant, Lauren. 2004. Compassion: The Culture and Politics of an Emotion. New York and London: Routledge.

Biekman, Barryl A. 2002. Gedenkboek Realisatie van Het Nationaal Monument Nederlands Slavernijverleden : Met de Menselijke Waardigheid Voor Ogen. Den Haag: Landelijk Platform Slavernijverleden.

Bijl, Paul. 2012. "Colonial Memory and Forgetting in the Netherlands and Indonesia." Journal of Genocide Research 14 (3-4): 441-61.

Blakely, Allison. 1993. Blacks in the Dutch World: The Evolution of Racial Imagery in a Modern Society. Bloomington [etc.]: Indiana University Press.

Bosma, Ulbe. 2009. Terug Uit de Koloniën: Zestig Jaar Postkoloniale Migranten En Hun Organisaties. Amsterdam: Bakker.

Buck-Morss, Susan. 2009. Hegel, Haiti, and Universal History. Illuminations: Cultural Formations of the Americas. Pittsburgh, PA: University of Pittsburgh Press.

Calhoun, Craig Jackson. 2010. "The Idea of Emergency." In Contemporary States of Emergency: The Politics of Military and Humanitarian Interventions, 29-58. New York: Zone Books.

Chouliaraki, Lilie. 2012. "Cosmopolitanism as Irony. A Critique of Post-Humanitarianism." In After Cosmopolitanism, edited by Rosi Braidotti, Patrick Hanafin, and Bolette Blaagaard, 77-96. Oxon and New York: Routledge.

Comaroff, J. L., and J. Comaroff. 2009. Ethnicity, Inc. Chicago and London: University of Chicago Press.

De Wilde, Mandy. 2015. "Brave New Neighbourhood. Affective Citizenship in Dutch Territorial Governance." PhD Dissertation, Amsterdam: University of Amsterdam.

Essed, Philomena, and Isabel Hoving. 2014. Dutch Racism. Amsterdam and New York: Rodopi.

Foucault, Michel. 1978. The History of Sexuality, Vol. 1, An Introduction. New York: Pantheon Books.

Geschiere, Peter. 2009. The Perils of Belonging: Autochthony, Citizenship, and Exclusion in Africa and Europe. Chicago and London: University of Chicago Press.

Gilroy, Paul. 2005. Postcolonial Melancholia. New York: Columbia University Press.

-- - 2009. Race and the Right to Be Human. Faculteit Geesteswetenschappen, Universiteit Utrecht.

Goslinga, Cornelis Christiaan. 1956. Emancipatie En Emancipator: De Geschiedenis van de Slavernij Op de Benedenwindse Eilanden En van Het Werk Der Bevrijding. Assen: Van Gorcum.

Horton, J. O., and J. C. Kardux. 2004. "Slavery and the Contest for National Heritage in the United States and the Netherlands." American Studies International 42 (2/3): 51-74.

Kesler, C.K. 1932. "Na 100 Jaar: Branden in Suriname." De West-Indische Gids, no. 15: 164-74.

Mepschen, Paul. 2016. "Everyday Autochthony. Difference, Discontent and the Politics of Home in Amsterdam." PhD Dissertation, Amsterdam: University of Amsterdam.

Mepschen, Paul, Jan Willem Duyvendak, and Evelien H. Tonkens. 2010. "Sexual Politics, Orientalism and Multicultural Citizenship in the Netherlands." Sociology 44 (5): 962-79.

Mepschen, Paul, Jan Willem Duyvendak, and Justus Uitermark. 2013. "Progressive Politics of Exclusion: Dutch Populism, Immigration, and Sexuality1." Migration and Citizenship 2 (1): 812.

Meyer, Birgit, and Peter Geschiere, eds. 1999. Globalization and Identity: Dialectics of Flow and Closure. Oxford [etc.]: Wiley-Blackwell.

Midden, Eva. 2014. "Towards a More Inclusive Feminism: Defining Feminism through Faith." In Transformations of Religion and the Public Sphere, edited by Rosi Braidotti, Bolette Blaagaard, Tobijn de Graauw, and Eva Midden, 210-27. Palgrave Politics of Identity and Citizenship Series. Palgrave Macmillan UK. 
Muehlebach, Andrea, and Nitzan Shoshan. 2012. "Introduction." Anthropological Quarterly 85 (2): 317-43.

Oostindie, Gert. 2001. Facing up to the Past: Perspectives on the Commemoration of Slavery from Africa, the Americas and Europe. Kingston: Ian Randle Publishers.

- - . 2010. Postkoloniaal Nederland; Vijfenzestig jaar vergeten, herdenken, verdringen. Amsterdam: Bert Bakker.

Oudenampsen, Merijn. 2013. "De Revolte van Nieuwrechts. Neoconservatisme En Postprogressieve Politiek." Krisis. Tijdschrift Voor Actuele Filosofie 32: 48.

Paasman, Albertus Nicolaas. 1984. Reinhart : Nederlandse Literatuur En Slavernij Ten Tijde van de Verlichting. Leiden: Nijhoff.

Passerini, Luisa. 2003. "Memories between Silence and Oblivion." Contested Pasts: The Politics of Memory, 238-54.

Prins, Baukje. 2002. "Het Lef Om Taboes Te Doorbreken. Nieuw Realisme in Het Nederlandse Discours over Multiculturalisme." Migrantenstudies 4: 241-54.

Schinkel, Willem. 2007. Denken in Een Tijd van Sociale Hypochondrie: Aanzet Tot Een Theorie Voorbij de Maatschappij. Kampen: Klement.

Sontag, Susan. 2004. Regarding the Pain of Others. London [etc.]: Penguin Books.

Spelman, Elizabeth V. 1998. Fruits of Sorrow: Framing Our Attention to Suffering. Beacon Press.

Stipriaan, Alex van. 2005. "Stilte! Niet Storen! De Slavernij Is Afgeschaft." De Negentiende Eeuw : Documentatieblad Werkgroep 19e Eeuw 29 (1): 45-61.

Stoler, Ann Laura. 2011. "Colonial Aphasia: Race and Disabled Histories in France." Public Culture 23 (1): 121-56.

Trouillot, Michel-Rolph. 1995. Silencing the Past: Power and the Production of History. Boston, MA: Beacon Press.

Uitermark, Justus, Paul Mepschen, and Jan Willem Duyvendak. 2013. "Populism, Sexual Politics, and the Exclusion of Muslims in the Netherlands." In European States and Their Muslim Citizens: The Impact of Institutions on Perceptions and Boundaries, 235-55. New York: Cambridge University press.

Verkaaik, Oskar, and Rachel Spronk. 2011. "Sexular Practice: Notes on an Ethnography of Secularism." Focaal 2011 (59): 83-88. 
' http://www.trouw.nl/tr/nl/4324/Nieuws/article/detail/1691966/2006/05/13/Red-ons-historischbesef.dhtml, accessed 17 February 2016.

ii Kramp, who was born in a poor family in Totness, in the Surinamese rural district of Coronie, is seen as a role model who has achieved a great career including a PhD, a government position in Suriname, and a position with the UNESCO despite his poor background (Chin A Foeng 2008).

iii See http://www.platformslavernijmonument.nl/toespraak3.php, accessed 19 November 2012.

iv http://www.platformslavernijmonument.nl/docs/speechvdPloeg1juli2000.pdf, accessed 26 November 2012.

${ }^{\vee}$ Susan Buck-Morrs has warned against 'conflating two silences, the past and the present one, when it comes to the Haitian story. For if men and women in the eighteenth century did not think in nonracial terms of the "fundamental equality of humanity," as "some of us do today," at least they knew what was happening; today, when the Haitian slaver revolution might be more thinkable, it ismore invisible, due to the construction of disciplinary discourses through which knowledge of the past has been inherited' (Buck-Morss 2009, 50). She argues that 'eighteenth century Europeans were thinking about the Haitian Revolution precisely because it challenged the racism of many of their preconceptions' (Buck-Morss 2009, 51), and that Hegel's famous master-slave dialectic is inspired by his intimate knowledge of current affairs, including the Haitian Revolution. However, this source of his thinking is never revealed explicitly, and it takes Buck-Morss' refined work to trace it. In other words, Hegel silenced the Haitian Revolution by talking about it in philosophical terms.

vi Keti Koti (lit. 'broken chains' or 'break the chains') is the Surinamese Creole (Sranantongo) term for abolition day, 1 July 1863.

vii Van Stipriaan (2005) quotes this article, arguing that it boils down to a distortion that replaces facts with a glorified nationalist fiction in which the cruelties of slavery or the agency of the enslaved have no room. Yet Van Stipriaan makes no mention of the extensive descriptions of violence in the very same article. 